\title{
ADVANCES IN DIRECT OXIDATION METHANOL FUEL CELLS
}

\author{
S. Surampudi, S.R. Narayanan, E. Vamos, H. Frank and G. Halpert \\ Jet Propulsion Laboratory \\ California Institute of Technology \\ Pasadena, CA 91109 \\ A. LaConti and J. Kosek \\ Giner, Inc. \\ Waltham, MA 02154-9147 \\ G.K. Surya Prakash and G.A. Olah \\ University of Southern California \\ Los Angeles, CA 90089-1661
}

\begin{abstract}
Fuel cells that can operate directly on fuels such as methanol are attractive for low to medium power applications in view of their low weight and volume relative to other power sources. A liquid feed direct methanol fuel cell has been developed based on a proton exchange membrane electrolyte and $\mathrm{Pt} / \mathrm{Ru}$ and $\mathrm{Pt}$ catalyzed fuel and air $/ \mathrm{O}_{2}$ electrodes respectively. The cell has been shown to deliver significant power outputs at temperatures of 60 to $90^{\circ} \mathrm{C}$. The cell voltage is near $0.5 \mathrm{~V}$ at $300 \mathrm{~mA} / \mathrm{cm}^{2}$ current density and an operating temperature of $90^{\circ} \mathrm{C}$. A deterrent to performance appears to be methanol crossover through the membrane to the oxygen electrode. Further improvements in performance appear possible by minimizing the methanol crossover rate.
\end{abstract}

\section{INTRODUCTION}

Direct oxidation methanol fuel cells (DMFC) are attractive for several defense and transportation applications in view of their lower weight and volume compared to indirect fuel cells $[1,2]$. The weight and volume advantages of direct oxidation fuel cells are due to the fact that they do not require any fuel processing equipment. Elimination of the fuel processor also results in simpler design and operation, higher reliability, less maintenance, and lower capital and operating costs. Further, direct oxidation fuel cells are projected to have rapid and multiple start up capabilities, and the ability to easily follow varying loads.

Under a task sponsored by the Defense Research Projects Agency (DARPA), JPL, USC, and Giner, Inc. are engaged in the development of direct methanol fuel cells for future defense applications. A near term objective of the program is to identify advanced catalysts and electrolytes and demonstrate the DMFC technology at the cell level. This paper describes the progress made to date on this effort.

\section{ASSESSMENT OF CATALYSTS FOR THE OXIDATION OF METHANOL}

Anodic oxidation behavior of methanol was investigated in half cells using both supported and unsupported catalysts at a loading of $0.5 \mathrm{mg} / \mathrm{cm}^{2}$. In these experiments $0.5 \mathrm{M}$ sulfuric acid was used 
as the electrolyte along with $0.001 \mathrm{M}$ perflurooctane sulfonic acid, and the fuel concentration was $1.0 \mathrm{M}$. These half cell experiments were carried out at $45^{\circ}$. Anodic oxidation characteristics of $\mathrm{CH}_{3} \mathrm{OH}$ at various unsupported (Pt-Sn and $\mathrm{Pt}-\mathrm{Ru}$ ) and supported catalysts (Pt, Pt-Sn and $\mathrm{Pt}-\mathrm{Ru}$ ) are given in Figures 1 and 2. It can be seen from these results that Pt-Ru is the most promising among the state-of-the-art Pt based catalysts for the oxidation of methanol. This observation is in agreement with the results reported in the literature $[3,4]$. All further studies were carried out using Pt-Ru catalyst.

Improved kinetics of methanol oxidation on Pt-Ru catalyst were observed with an increase in temperature, catalyst loading and methanol concentration. Figure 3 reveals a significant reduction of polarization as the temperature is raised from 25 to $60^{\circ} \mathrm{C}$. Throughout the current density range of 1 to $100 \mathrm{~mA} / \mathrm{cm}^{2}$ the polarization is reduced almost $100 \mathrm{mV}$ by this temperature increase. Figure 4 gives the results of the catalyst loading studies. Results show that the increase from 1 to $5 \mathrm{mg} / \mathrm{cm}^{2}$ resulted in the reduction of almost $100 \mathrm{mV}$ polarization throughout the current density range from 1 to $100 \mathrm{~mA} / \mathrm{cm}^{2}$. Increasing the methanol concentration also resulted in lower anodic polarization for the oxidation of methanol (Figure 5).

\section{EVALUATION OF ELECTROLYTES FOR THE OXIDATION OF METHANOL}

\section{Liquid Electrolytes}

Boron trifluoride dihydrate, triflic acid, perfluoroethane sulfonic acid and perflurooctane sulfonic acid $\left(\mathrm{C}_{8}\right.$ acid) were evaluated as candidate electrolytes for the oxidation of methanol. Experiments were carried out in half cells using activated $\mathrm{Pt}-\mathrm{Ru}$ gas diffusion electrodes obtained from commercial sources. Pt-Ru electrodes were found to be unstable and dissolve in boron trifluoride dihydrate electrolyte. Hence no further experiments ere carried out with this electrolyte. Anodic oxidation characteristics of methanol in the other three electrolytes are given in Figure 6. Some of the important findings of this study are: a) anodic oxidation of methanol in triflic acid is comparable to its oxidation is sulfuric acid, b) perfluroethanesulfonic acid was found to be unattractive for the oxidation of methanol, and c) marginally improved oxidation behavior was observed with perflurooctanesulfonic acid electrolyte.

Solid Polymer Electrolytes

Nafion, a polymer electrolyte membrane (PEM), is an attractive alternate to the liquid electrolytes for liquid feed methanol cells for several reasons including: a) simplified design, b) simplified assembly and operation, c) lower corrosion, and d) minimization or elimination of shunt currents. The material has been used quite successfully in gas feed hydrogen/oxygen fuel cells.

For these reasons, Nafion was evaluated as an electrolyte in a liquid feed half cell. A methanol-water mixture only (without acid) was introduced to the fuel compartment. Nafion 117 (Du Pont) was used, and the anode catalyst was a supported Pt-Ru type that was bonded directly to the Nafion. Figure 7 compares performance of this cell with the Nafion electrolyte to the previously employed sulfuric acid electrolyte. Hence, Nafion was selected as the candidate electrolyte in all further studies. 


\section{CELL DESIGN}

\section{Design Optimization}

Two cell design options were considered for direct oxidation methanol fuel cells including: a) gas or vapor feed design and b) liquid feed design. Initial considerations indicated that gas feed design is preferable in that it could employ existing fuel cell type gas diffusion electrodes. Furthermore, the gas feed design could operate at the higher temperatures that were anticipated to be necessary for high performance. Subsequent deliberations considered the fact that the liquid feed design would not require a vaporizer and would therefore be much simpler in design and operation. The other potential advantages of liquid-feed design are: a) elimination of complex water and thermal management systems, b) multiple use capability of the methanol-water as the fuel, for humidification purposes and as an efficient stack coolant, and c) significantly lower system size and weight. This cell design does not suffer from the disadvantages of prior liquid-feed cell designs which employed liquid electrolytes. The use of PEM eliminates the problem of troublesome shunt currents and also eliminates problems associated with corrosion of cell components. Tests have shown that the PEM does not degrade with operation and is suitable for continuous operation. Fuel catalysts were found to exhibit improved performance with the solid electrolyte membrane. On this basis JPL began development of liquid feed type direct methanol fuel cells.

\section{Schematic Diagram of Liquid Feed Direct Methanol Fuel Cells}

Figure 7 give a schematic diagram of the complete laboratory type liquid feed methanol system employing the membrane electrolyte. The MEA (membrane-electrode assembly) consists of a layer of Nafion electrolyte 7 mil thick with fuel and air $/ \mathrm{O}_{2}$ electrodes bonded to either side. Electrode dimensions are 2 inch by 2 inch by approximately 10 mil thick. The MEA is positioned between the machined portion of two graphite blocks. The machined area on each block is a rectangular pattern with open channels (designated as the flow field) to allow flow of liquid or gas across the electrode surfaces. Inlet and outlet ports communicate with the flow fields via holes drilled into the carbon blocks and equipped with threaded fittings at the sides of the blocks. Stainless steel support plates, with the same overall length and width as the carbon plates, are located on the back surface of the plates. The stainless steel plates as well as the carbon blocks are drilled in their outer perimeter to accommodate bolts that are used to compress the assembly for sealing and to provide electrical contact between the electrode and un-recessed area of the flow field.

The methanol solution is introduced into the fuel compartment of the cell via a pump and then returned to a fuel storage reservoir as shown in Figure 8. The end product, carbon dioxide, is entrapped in the exit fuel line and released in the storage reservoir. Pressurized air or $\mathrm{O}_{2}$ is introduced to the air compartment of the cell and vented without circulation. Heaters are located on the outside surface of the cell to control sell temperature. Finally, the cell is equipped with a small closed end hole to accommodate an internal thermocouple.

\section{PERFORMANCE OF LIQUID FEED DIRECT METHANOL FUEL CELLS}

Effect of Temperature

Voltage-current characteristics of the liquid feed direct methanol fuel cell were measured over a range of temperatures with $2 \mathrm{M}$ methanol as fuel and pure $\mathrm{O}_{2}$ as oxidant. Results are given in Figure 9 in terms of operating cell potential versus current density. Each point represents an 
essentially steady state voltage that was achieved after about 5 minutes of continuous operation at the indicated current density. Inspection of Figure 8 reveals a marked increase in performance with increase in temperature over the range of $30^{\circ} \mathrm{C}$ to $90^{\circ} \mathrm{C}$. For example, at a potential of $0.55 \mathrm{~V}$, the current density outputs are 10,45 , and $140 \mathrm{~mA} / \mathrm{cm}^{2}$ at temperatures of 30,60 , and $95^{\circ} \mathrm{C}$ respectively. Similarly, at a potential of $0.50 \mathrm{~V}$, the current density outputs are 20,110 , and $260 \mathrm{~mA} / \mathrm{cm}^{2}$ at 30,60 and $95^{\circ} \mathrm{C}$. The trend of increased output with increase in temperature is in accord with that exhibited by other fuel cells. The increased output at higher temperatures is attributed to a combination of factors consisting of a reduction of cell ohmic resistance, activation polarization, and concentration polarization.

Effect of Methanol Concentration

The effect of methanol concentration on the cell performance was also determined. Three separate runs were carried out at $60^{\circ} \mathrm{C}$ each with a different fuel concentration of $0.5 \mathrm{M}, 2.0 \mathrm{M}$, and 4.0 M methanol. The effect of fuel concentration on overall cell performance is given in Figure 10 in terms of voltage-current characteristics. Inspection of these results shown that a higher operating current densities, higher cell voltage is obtained with $2 \mathrm{M}$ methanol while somewhat lower outputs are obtained with both the higher concentration, $4 \mathrm{M}$ methanol, and the lower concentration, $0.5 \mathrm{M}$ methanol. At lower current densities $0.5 \mathrm{M}$ methanol was found to provide higher cell operating voltage than $2.0 \mathrm{M}$ methanol. On this basis there appears to be an optimum concentration for operation for different current densities. The optimum may be between $0.5 \mathrm{M}$ and $2 \mathrm{M}$ methanol. The lower performance of the cell at fuel concentrations less than $0.5 \mathrm{M}$ is probably due to the concentration polarization effects. The poor performance of the cell at higher methanol concentrations was found to be due to the fuel crossover phenomenon. Support for the proposed impact of crossover at high concentrations was shown in half cell studies on the oxygen electrode. It was found that the $\mathrm{O}_{2}$ electrode performance is significantly lowered at higher methanol concentrations [5]. For example, the $\mathrm{O}_{2}$ electrode potential dropped more than $100 \mathrm{mV}$ at $100 \mathrm{~mA} / \mathrm{cm}^{2}$ as methanol concentration was increased from 2 to $4 \mathrm{M}$ methanol. This finding emphasizes the need to minimize the crossover rate to improve performance of the $\mathrm{O}_{2}$ electrode and hence the overall cell performance.

\section{Fuel Utilization Studies}

In order to examine fuel utilization, a cell was set up and run continuously at constant current with a finite amount, $200 \mathrm{ml}$ of $1.0 \mathrm{M}$ methanol solution in the circulation tank, without replenishment of the methanol. Initially the current was set at $1.875 \mathrm{~A}\left(75 \mathrm{~mA} / \mathrm{cm}^{2}\right)$, and the cell temperature was held at $80^{\circ}$. Results are given in Figure 11 in terms of cell voltage versus percent utilization of the fuel. The utilization was taken as output amp-hrs/theoretical amp-hrs (from the amount of methanol and its electrochemical equivalent). Inspection of this figure reveals that voltage drops sharply at $75 \mathrm{~mA} / \mathrm{cm}^{2}$ when utilization approaches $60 \%$. The sharp drop in voltage at this point is believed to be associated with concentration polarization of the fuel electrode that is, in turn, due to an inadequate supply of methanol to the electrode. The methanol supply is, in turn, limited by the low methanol concentration at this point (near $0.5 \mathrm{M}$ or less). The phenomenon is consistent with prior half cell studies that revealed the onset of high polarization when methanol concentration declines below this level.

\section{PROBLEMS AND ISSUES}

Performance of the liquid feed methanol fuel cells is already attractive for some applications and is approaching the levels required for electric vehicle propulsion. With some improvements in 
electrical performance, efficiency and cost, this system can indeed be considered a serious candidate for electric vehicle applications. These improvements can be achieved by developing high performance anode catalysts, new membranes with reduced methanol permeability, methanol insensitive cathode catalysts, and low cost materials (non-Pt based catalysts, membranes, bipolar plate materials, etc.).

\section{CONCLUSIONS}

Some of the major finding of the study are:

1) $\mathrm{Pt} / \mathrm{Ru}$ catalyzed electrodes are well suited for oxidation of methanol.

2) Performance of $\mathrm{Pt} / \mathrm{Ru}$ catalyzed carbon electrodes increases with increased temperatures (25 to $\left.60^{\circ} \mathrm{C}\right)$, increased fuel concentration, $(0.5$ to $2 \mathrm{M}$ methanol) and increased catalyst loading $\left(0.5\right.$ to $\left.5 \mathrm{mg} / \mathrm{cm}^{2}\right)$.

3) A new liquid feed DMFC has been developed based on a proton exchange membrane electrolyte, $\mathrm{Pt} / \mathrm{Ru}$ catalyzed fuel electrode, and $\mathrm{Pt}$ catalyzed air $/ \mathrm{O}_{2}$ electrodes.

4) The new cell can deliver significant outputs in excess of $250 \mathrm{~mA} / \mathrm{cm}^{2}$ at potentials near $0.5 \mathrm{~V}$ at moderate temperatures (less than $190^{\circ} \mathrm{F}$ ).

\section{ACKNOWLEDGEMENT}

The work described here was carried out at the Jet Propulsion Laboratory, California Institute of Technology, in a program sponsored by ARPA under contract with the National Aeronautics and Space Administration.

\section{REFERENCES}

1) S.D. Fritts and R.K. Sen, Assessment of Methanol Electro-Oxidation for Direct Methanol-Air Fuel Cells, DOE Report PNL-6077 (1988).

2) S. Surampudi, S.R. Narayanan, E. Vamos, H. Frank and G. Halpert, Proceedings of the Eighth Annual Battery Conference on Applications and Advances, Long Beach, CA (January 1993).

3) M.M.P. Jansen and J. Moolhuysen, Electrochim. Acta, 21, 869 (1976).

4) M. Watanabe, M. Uchida and S. Moto, J. Electroanal. Chem., 229, 395 (1987).

5) S.R. Narayanan, E. Vamos, S. Surampudi, H. Frank and G. Halpert, Extended Abstracts of the Fall 1993 Meeting of the Electrochemical Society, in press. 


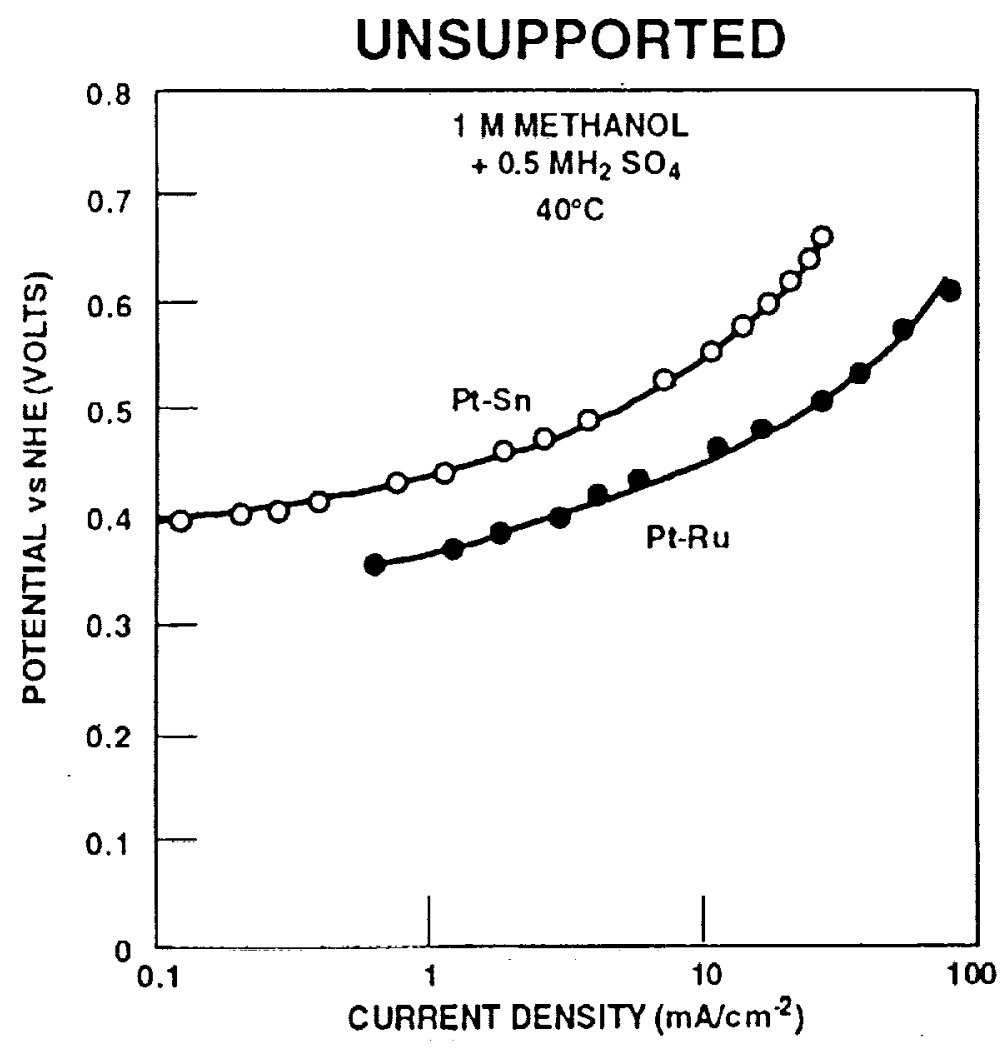

Figure 1. Evaluation of Unsupported Catalysts for Methanol Oxidation.

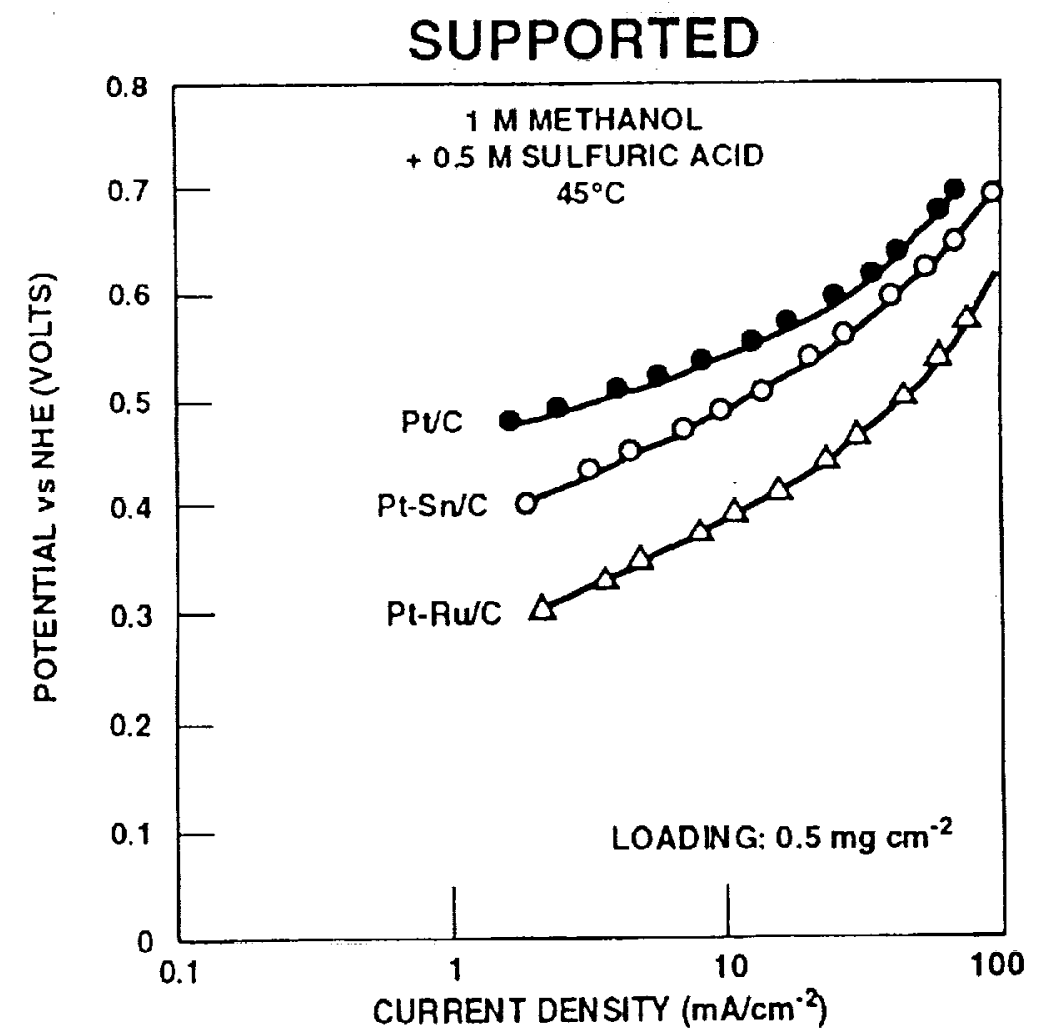

Figure 2. Evaluation of Supported Catalysts for Methanol Oxidation. 


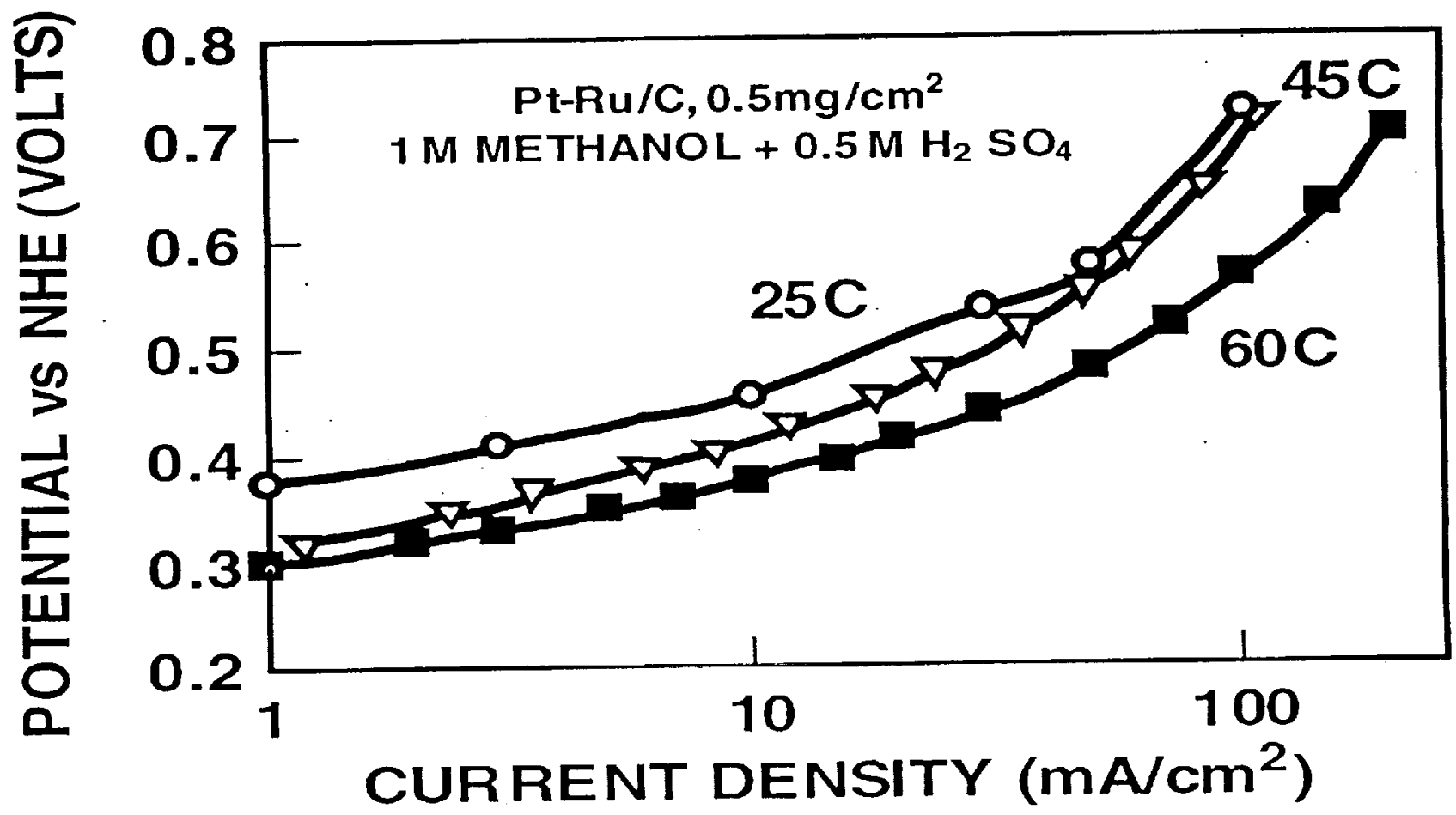

Figure 3. Effect of Temperature on Performance of Pt/Ru Electrodes.

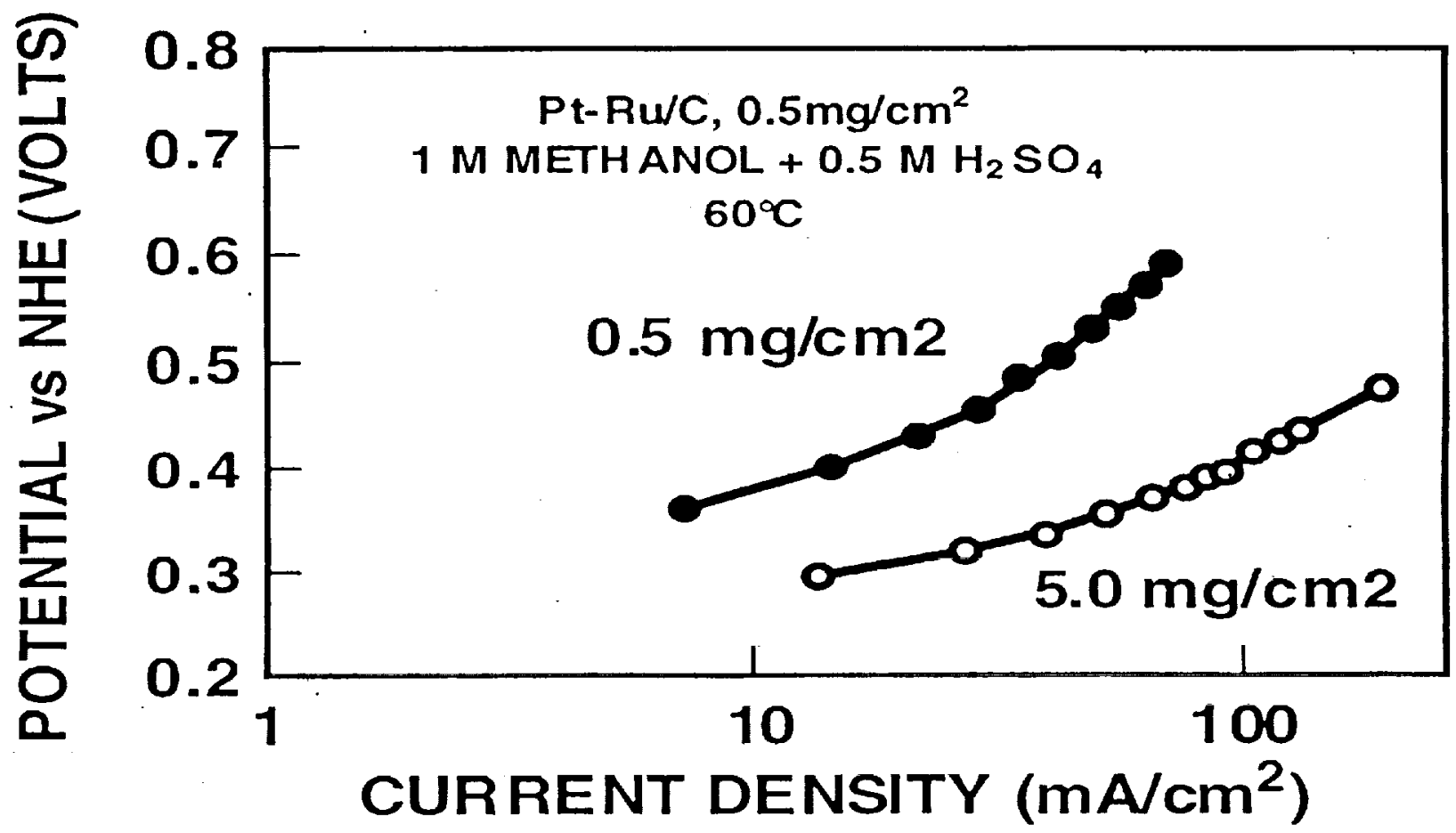

Figure 4. Effect of Catalyst Loading on Performance of $\mathrm{Pt} / \mathrm{Ru}$ Electrodes. 


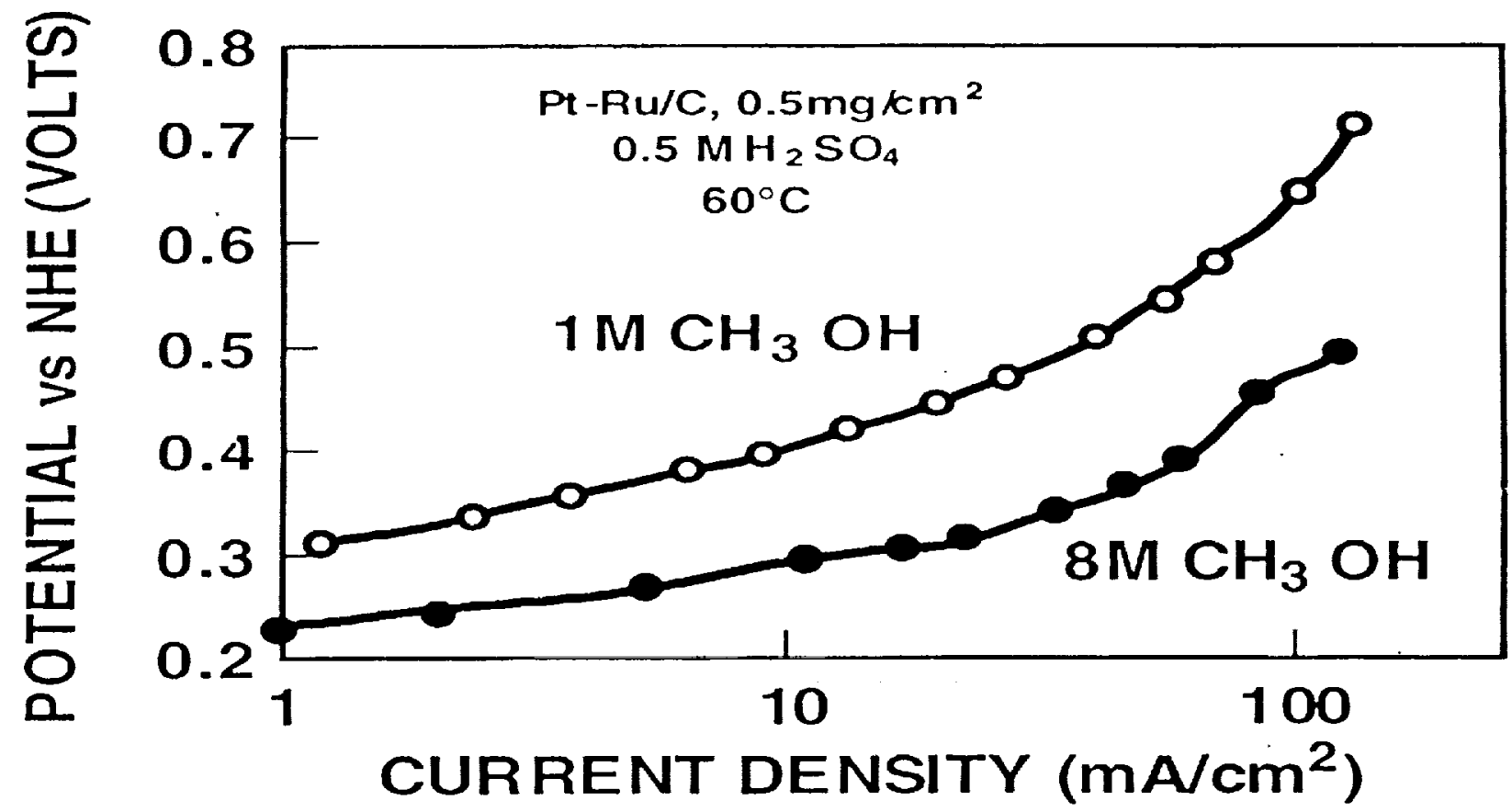

Figure 5 Effect of Fuel Concentration on Performance of Pt/Ru Electrodes.

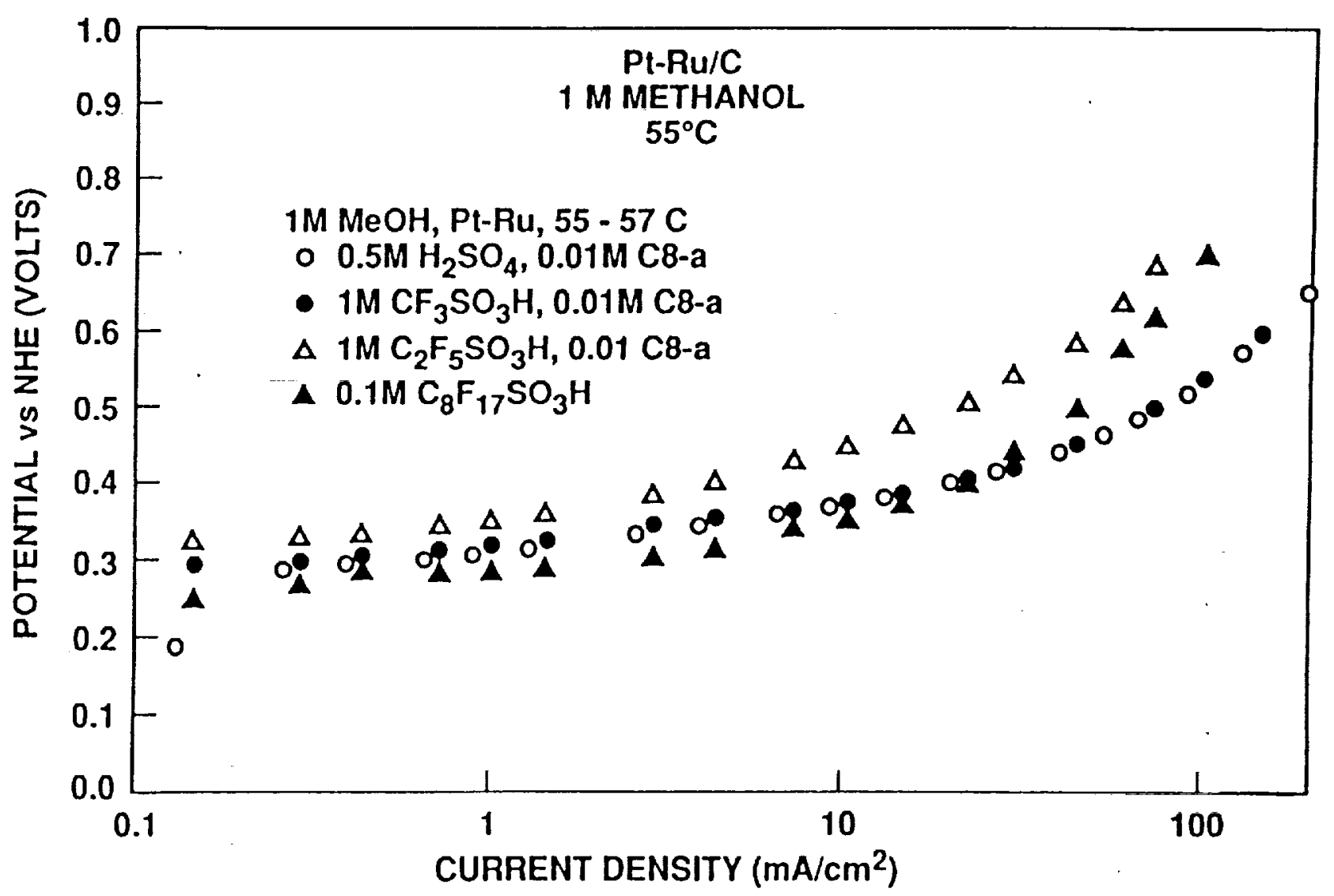

Figure 6. Anodic Oxidation of Methanol in Various Electrolytes. 


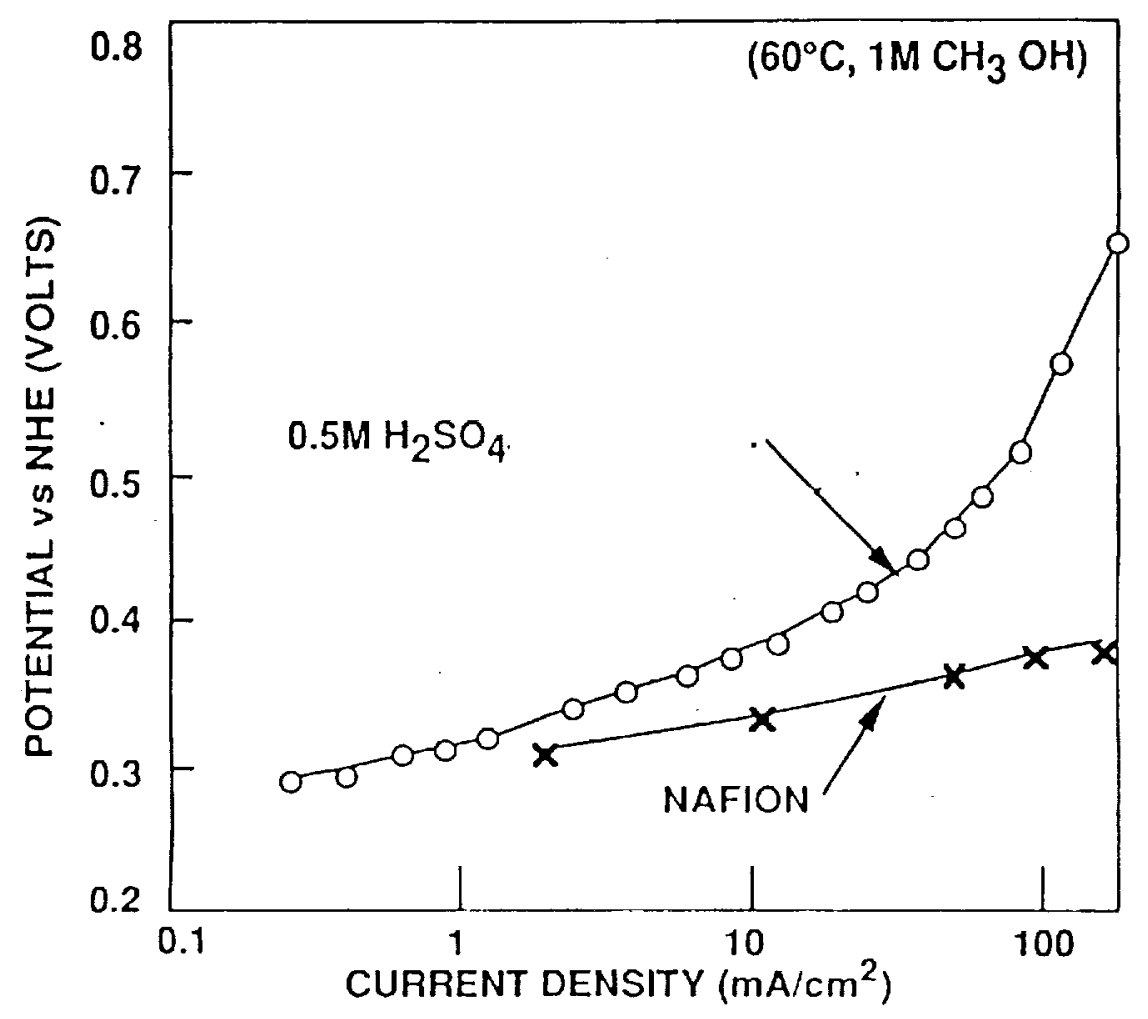

- IMPROVE FUEL OXIDATION CHARACTERISTICS WITH NAFION

Figure 7. Evaluation of Electrolytes for Anodic Oxidation of $\mathrm{CH}_{3} \mathrm{OH}$.

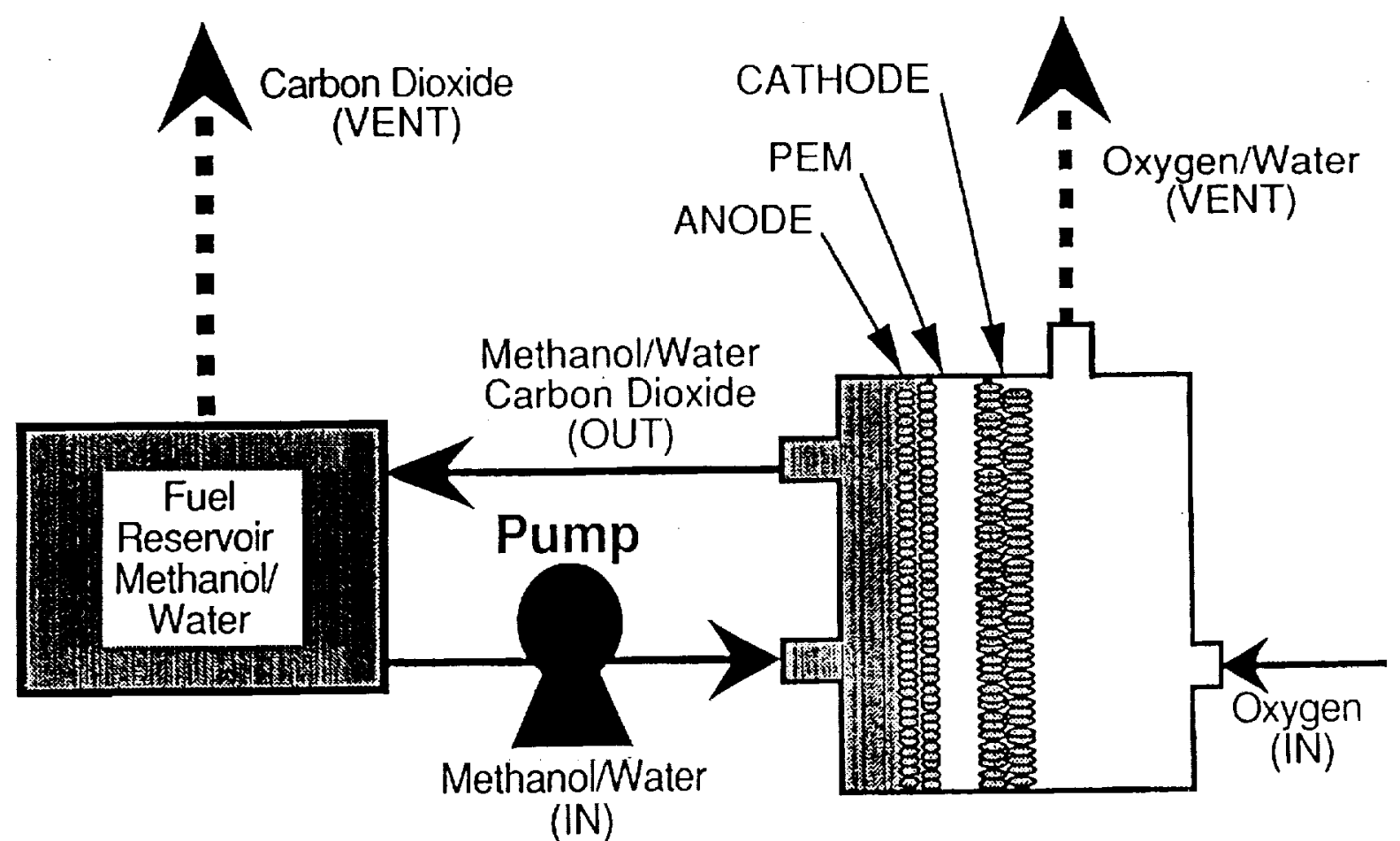

Figure 8. Diagram of JPL Liquid Feed Direct Methanol Fuel Cell. 


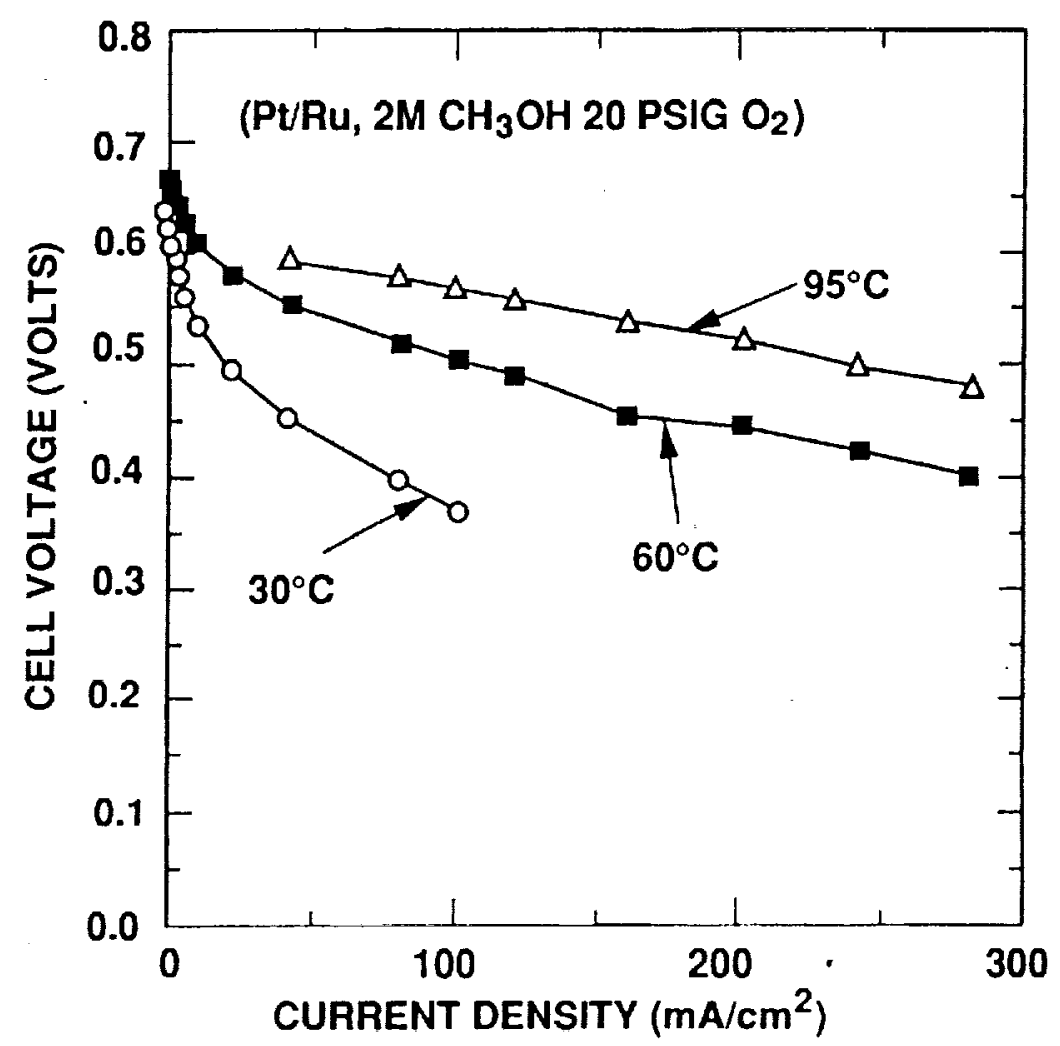

Figure 9. Effect of Temperature on Cell Performance.

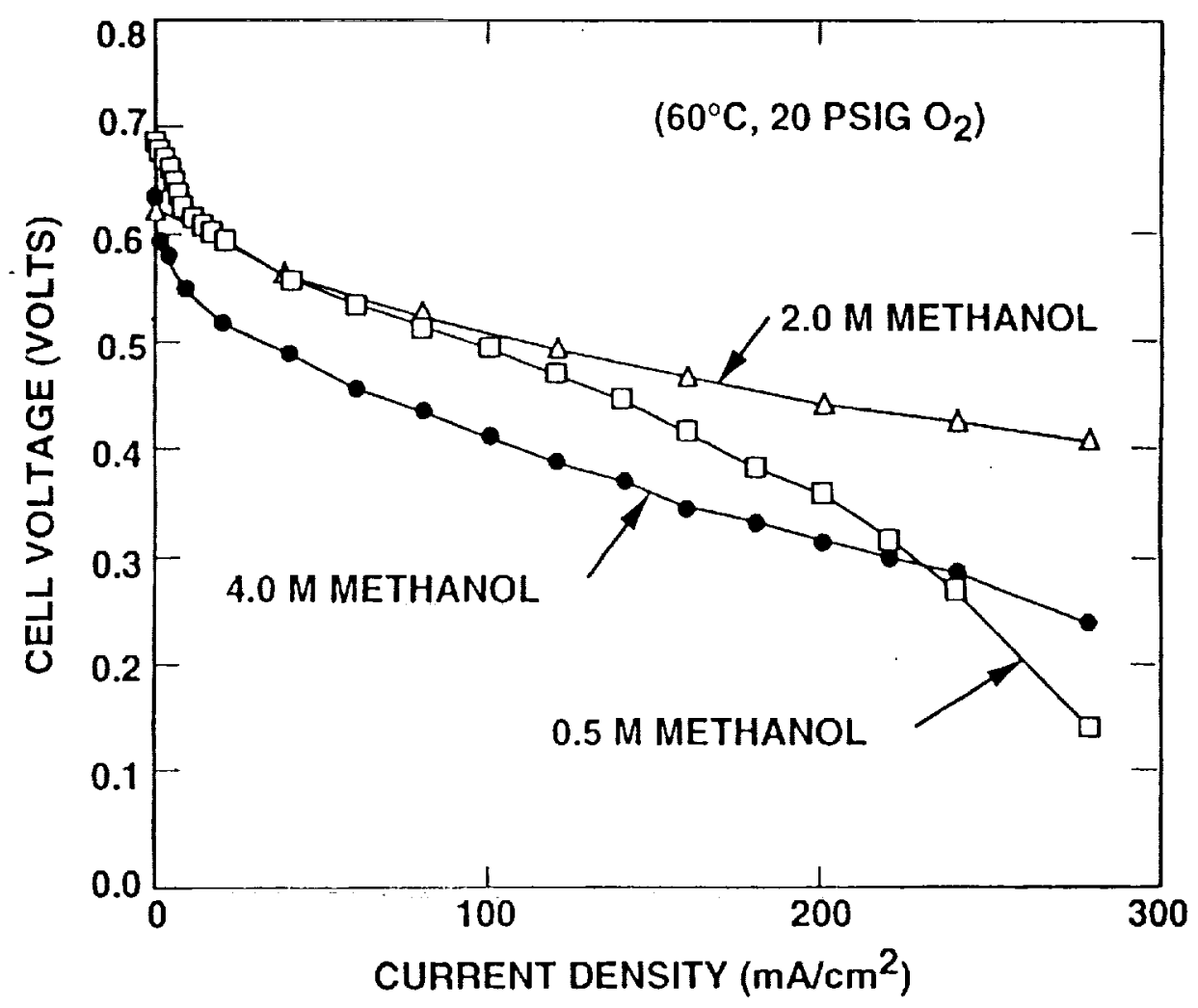

Figure 10. Effect of Fuel Concentration on Cell Performance. 


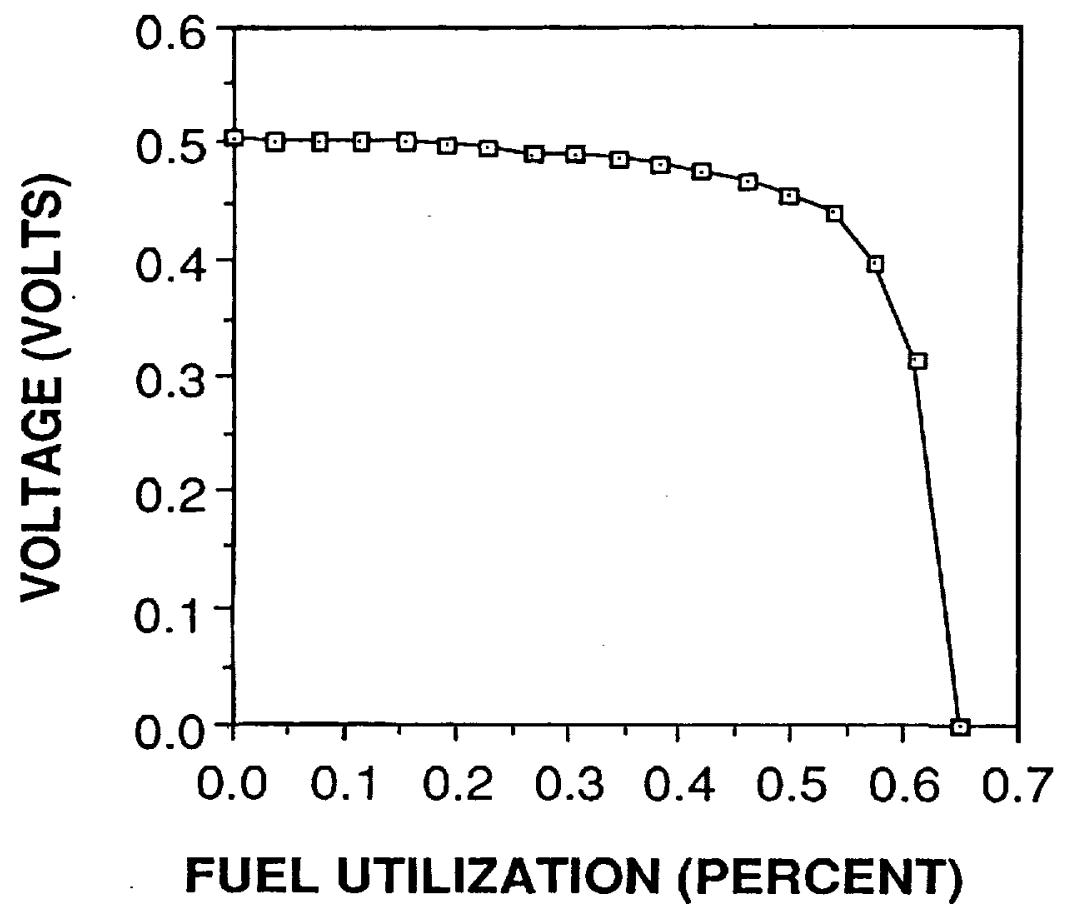

Figure 11. Voltage vs Fuel Utilization Curve. Current Density, $62^{\circ} \mathrm{C}$. 20 PSIG Oxygen. $1 \mathrm{M}$ Methanol Initial Concentration, $75 \mathrm{~mA} / \mathrm{cm}^{2}$ 
